\title{
Kinetic Study of Subcritical Water Extraction of Scopoletin, Alizarin, and Rutin from Morinda citrifolia
}

\author{
Roslina Jamaludin ${ }^{1,2,+}$, Dong-Shin Kim ${ }^{3,+}$, Liza Md Salleh ${ }^{1,2}$ and Sang-Bin Lim ${ }^{3, *(1)}$ \\ 1 Centre of Lipids Engineering \& Applied Research (CLEAR), Ibnu Sina Institute for Scientific and Industrial \\ Research, Universiti Teknologi Malaysia, UTM, Johor Bahru 81310, Johor, Malaysia; \\ roslina_9@yahoo.com (R.J.); r-liza@utm.my (L.M.S.) \\ 2 Department of Bioprocess and Polymer Engineering, School of Chemical and Energy Engineering, Faculty of \\ Engineering, Universiti Teknologi Malaysia, UTM, Johor Bahru 81310, Johor, Malaysia \\ 3 Department of Food Bioengineering, Jeju National University, Jeju 63243, Korea; feel567@naver.com \\ * Correspondence: sblim@jejunu.ac.kr; Tel.: +82-64-754-3617 \\ + The authors contributed equally to this work.
}

Citation: Jamaludin, R.; Kim, D.-S.; Salleh, L.M.; Lim, S.-B. Kinetic Study of Subcritical Water Extraction of Scopoletin, Alizarin, and Rutin from Morinda citrifolia. Foods 2021, 10, 2260. https://doi.org/10.3390/

foods 10102260

Academic Editor: Edy Sousa Brito

Received: 3 September 2021

Accepted: 22 September 2021

Published: 24 September 2021

Publisher's Note: MDPI stays neutral with regard to jurisdictional claims in published maps and institutional affiliations.

Copyright: (c) 2021 by the authors. Licensee MDPI, Basel, Switzerland. This article is an open access article distributed under the terms and conditions of the Creative Commons Attribution (CC BY) license (https:// creativecommons.org/licenses/by/ $4.0 /)$.

\begin{abstract}
Noni fruits (Morinda citrifolia) are a source of phenolic bioactive compounds (scopoletin, alizarin, and rutin), which have antioxidant, antimicrobial, anticancer, and anti-inflammatory activities. In this study, subcritical water was applied to determine the extraction yields and kinetics of phenolic compounds from noni fruits. The scopoletin and alizarin yields increased with the increase in temperature from 100 to $140{ }^{\circ} \mathrm{C}$, while that of rutin increased up to $120^{\circ} \mathrm{C}$ and then decreased at $140{ }^{\circ} \mathrm{C}$. The yields of all the compounds rapidly increased from 1 to $2 \mathrm{~mL} / \mathrm{min}$ and then slightly up to $3 \mathrm{~mL} / \mathrm{min}$ of water flow rate. The extraction kinetics were assessed using two mathematical models. The two-site kinetic desorption model had a better fit for all experimental conditions throughout the extraction cycle and best described the extraction kinetics of phenolic compounds from noni fruits. The diffusion coefficients of scopoletin and alizarin at $140{ }^{\circ} \mathrm{C}$ and $3 \mathrm{~mL} / \mathrm{min}$ were 3.7 - and 16.2 -fold higher than those at $100{ }^{\circ} \mathrm{C}$ and $1 \mathrm{~mL} / \mathrm{min}$, respectively. The activation energies of alizarin were 2.9 - to 8.5 -fold higher than those of scopoletin at various flow rates. Thus, subcritical water could be an excellent solvent with higher extraction yields and shorter extraction times using an environmentally friendly solvent.
\end{abstract}

Keywords: Morinda citrifolia; subcritical water extraction; scopoletin; alizarin; rutin; kinetic study

\section{Introduction}

Noni (Morinda citrifolia), also known as mengkudu in Malaysia, which belongs to the Rubiaceae family, is native to Southeast Asia and has been cultivated and naturalized across Australia and the Pacific Islands. Noni has been used as traditional Polynesian medicines and is often consumed to treat high blood pressure, stimulate the immune system, and treat bacterial, viral, fungal infections and many more. Its ability to treat various illnesses has led numerous scientific studies to be carried out to investigate phytochemicals and their pharmacological activities from different parts of noni [1-3].

Noni contains various phytochemicals that are important for foods, supplements, and nutraceuticals. About 200 phytochemicals have been identified in noni, and the major groups of functional components are phenolics, alkaloids, and organic acids. Among them, the most important are scopoletin (phenolic coumarin), alizarin, rutin, damnacanthal, morindone, morindin, aucubin, asperulose, rubiadin, and anthraquinone glycosides [4-7].

Scopoletin is one of the most important coumarins in noni fruits. It possesses a variety of pharmacological effects, such as ameliorated hyperglycemia and hepatic steatosis [8], and anti-inflammatory activity [9]. Alizarin is found mainly in noni roots with small traces in fruits and leaves. It has an antiangiogenic effect by blocking blood circulation to malignant tumors and could be a potential antitumor drug for bone cancer $[6,10,11]$. Another interesting phenolic compound is rutin, which possesses antiadrenergic and antidopaminergic activities [12] and diabetic cardiomyopathy characteristics [13]. 
Selecting the suitable extraction method is a crucial step to produce high yields of phenolic compounds from noni fruits for functional foods and nutraceuticals. There are green processing technologies that can be applied to extract phenolic compounds from biomaterials, such as supercritical fluid, microwave-assisted, subcritical water (SW), and hydrostatic pressure extractions [14-16]. Increased interests have been recorded in the use of SW for the extraction of phenolic compounds from plant or various biomass materials due to its eco-friendly method by using only water as main solvent. SW typically refers to the state of liquid water retained by pressure beyond the boiling point $\left(100^{\circ} \mathrm{C}\right)$, up to the state of its critical temperature $\left(374^{\circ} \mathrm{C}\right)$. The occurring breakdown of the intermolecular hydrogen bonds due to the subcritical state causes a corresponding decrease in polarity of the water. The interesting point of SW is that the dielectric constant, viscosity, and surface tension of water can be adjusted by applying different operational temperatures. Therefore, SW can become an effective extraction solvent for medium polar and nonpolar compounds [15,17-21].

During SW extraction (SWE), the bound solute inside the cells is extracted from the sample matrix, and then is drained to the solvent $[22,23]$. Investigating the extraction mechanisms based on mathematical kinetic models can help understand the extraction process [24-26]. This will provide useful information for scale-up and designing of new commercial subcritical water extraction devices [22,25].

Several research studies have been performed on the modeling of SWE kinetics for: damnacanthal from roots of $M$. citrifolia [25], carbohydrates and phenolics from flax shives [22], anthraquinones from Heterophyllaea pustulata [26], polyphenols from grape by-products [27], rutin from Fagopyrum esculentum [28], and bioactive compounds from malted quinoa [29]. To the best of our knowledge, there have been no research studies reported on the extraction kinetic modeling of scopoletin, alizarin, and rutin from noni fruits using SW.

In this study, the effect of operating parameters (water temperature and flow rate) using SW on the recovery and extraction kinetics of phenolic bioactive compounds from noni fruits was investigated. Two mathematical kinetic models (two-site kinetic and partition coefficient models) were compared to investigate the mechanism controlling the extraction rates using $\mathrm{SW}$.

\section{Materials and Methods}

\subsection{Sample Material and Chemicals}

Noni fruits were obtained from Johor, Malaysia; washed using tap water; sliced to about $5 \mathrm{~mm}$; and freeze-dried overnight until a constant weight was achieved for $32 \mathrm{~h}$. The dried whole fruits with seeds and skins (moisture content: $5.82 \pm 0.06 \%$ ) were then ground using a Waring blender (mean particle size of $575 \mu \mathrm{m}$ ). Scopoletin ( $\geq 99 \%)$ and alizarin $(97 \%)$ were purchased from Sigma Chemical Co. (St. Louis, MO, USA). Rutin ( $\geq 95 \%)$ was purchased from Santa Cruz Biotechnology, Inc. (Santa Cruz, CA, USA). High pressure liquid chromatography (HPLC)-grade acetonitrile (99.8\%), methyl alcohol $(99.9 \%)$, and formic acid (99\%) were obtained from Sigma Chemical Co.

\subsection{Methanol Extraction}

To determine the amounts of scopoletin, rutin, and alizarin in the dried raw sample, solvent extraction with methanol was carried out. The dried noni fruits $(0.5 \mathrm{~g})$ were added to methanol $(20 \mathrm{~mL})$ and stirred for $30 \mathrm{~min}$. The mixture was centrifuged $(3000 \times \mathrm{g}, 10 \mathrm{~min})$ to separate the supernatant, and the residue was extracted four more times until all three compounds were quantitatively recovered. The extract was evaporated using a vacuum rotary evaporator, redissolved in methanol, and filtered using a syringe filter $(0.45 \mu \mathrm{m})$ for HPLC analysis. The analysis data of phenolic compounds were averaged with three replicates. 


\subsection{Subcritical Water Extraction}

SWE was carried out in our custom-made semicontinuous extractor (Figure 1) described previously by Kim and Lim [28]. The extraction method is briefly described here. The freeze-dried noni fruit powder $(2 \mathrm{~g})$ was mixed with sea sand and loaded in the stainless steel extraction cell (7.8 mm i.d. $\times 300 \mathrm{~mm}$ length). Glass wool was inserted at both ends of the extractor to prevent plugging. The extraction process was commenced by switching on the oven as soon as the temperature set point was reached. The degassed water was supplied by a piston pump (Thermo Separation Products, Waltham, MA, USA). To retain the liquid state of the water at high temperature, the pressure of the water was maintained at $5 \mathrm{MPa}$. The water flow rate was controlled by a high-pressure metering valve (Parker Autoclave Engineers, Erie, PA, USA). The extracts were taken every $2.5 \mathrm{~min}$ for $20 \mathrm{~min}$. The water temperatures studied in this work were 100,120 , and $140^{\circ} \mathrm{C}$ with water flow rates of 1,2 , and $3 \mathrm{~mL} / \mathrm{min}$ based on our preliminary experiments. All the experiments were repeated three times.

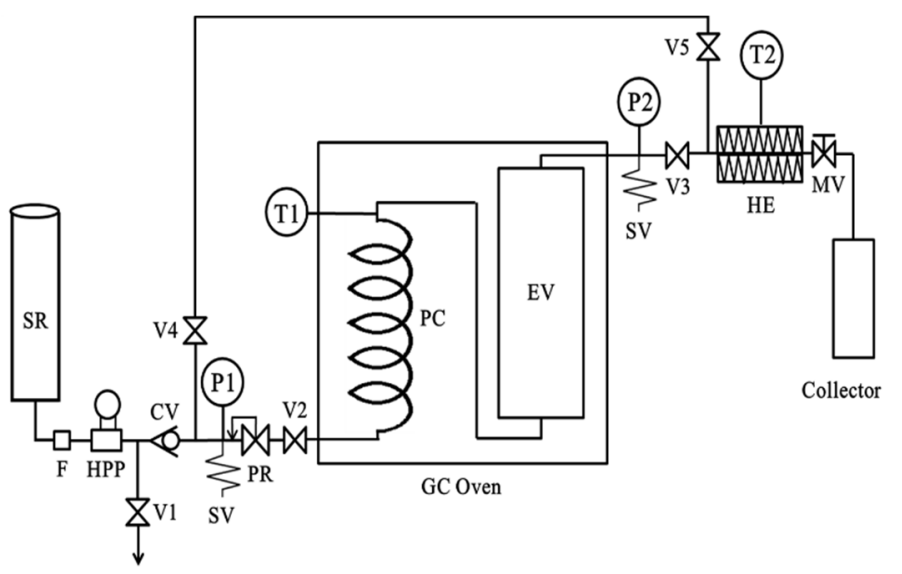

Figure 1. Semicontinuous subcritical water extraction system $(\mathrm{CV}$, check valve; $\mathrm{EV}$, extraction vessel; $\mathrm{F}$, filter; HE, heat exchanger; HPP, high-pressure pump; MV, metering valve; $p$, pressure gauge; $\mathrm{PC}$, preheating coil; $\mathrm{PR}$, pressure regulator; $\mathrm{SV}$, safety valve; $\mathrm{SR}$, solvent reservoir; $\mathrm{T}$, temperature indicator; $\mathrm{V}$, on/off valve).

\subsection{HPLC Analysis}

The contents of phenolic compounds in the extracts were measured by HPLC (Alliance 2965, Waters Corp., Milford, MA, USA) described previously by Kim and Lim [28]. The analysis method is briefly described here. The phenolic compounds were separated on an XTerra ${ }^{\circledR}$ C18 column $(250 \times 4.6 \mathrm{~mm}, 5 \mu \mathrm{m}$ film thickness; Waters Corp, Milford, MA, USA). The mobile phases consisted of $0.5 \%$ formic acid (A) and acetonitrile (B). It was initially set at $80 \% \mathrm{~A}$ and $20 \% \mathrm{~B}$, and then the ratio of solvent $\mathrm{B}$ was changed as follows: to $20 \%$ over $15 \mathrm{~min}$, to $70 \%$ over $20 \mathrm{~min}$, and to $20 \%$ over $30 \mathrm{~min}$. The mobile phase flow rate was $1.0 \mathrm{~mL} / \mathrm{min}$. The detection of scopoletin and rutin was performed at $350 \mathrm{~nm}$, while that of alizarin at $250 \mathrm{~nm}$ using a photodiode array detector (Alliance 2998, Waters Corp.). Quantification was performed by comparing the chromatographic peak areas with those of external standards (Figures S1-S3).

\subsection{Kinetic Modeling}

To describe the extraction kinetics of phenolic compounds under subcritical conditions, two kinetic models were applied. The partition coefficient model assumes that the thermodynamic equilibrium mainly controls the extraction process [30]. The extraction curve for the partition coefficient model is given in Equation (1):

$$
\frac{S_{b}}{S_{0}}=\frac{S_{a}}{S_{0}}+\frac{1-S_{a} / S_{0}}{1+K_{D} m / \rho\left(V_{b}-V_{a}\right)}
$$


where $S_{0}$ is the initial solute $(\mathrm{mg} / \mathrm{g})$ in the raw noni fruits; $S_{a}$ and $S_{b}$ are the extracted solutes $(\mathrm{mg} / \mathrm{g})$ using water $V_{a}$ and $V_{b}(\mathrm{~mL})$, respectively; $m$ and $\rho$ are the sample $(\mathrm{mg})$ and density of water $(\mathrm{mg} / \mathrm{mL})$ under given temperatures; and $K_{D}$ is the equilibrium partitioning coefficient. The model parameters were determined using the Microsoft Excel software.

The two-site kinetic model considers the extraction controlled by an internal diffusion. Two types of rate constants, $k_{1}$ (for the fast-released fraction, $f$ ) and $k_{2}$ (for the slowly released fraction, $1-f$ ), are used to describe the extraction curve [27]. The mathematical expression for calculating the total mass of solute recovered after time $t$ is as follows:

$$
\frac{S_{t}}{S_{0}}=1-\left(f \exp \left(-k_{1} t\right)\right)-\left[(1-f) \exp \left(-k_{2} t\right)\right]
$$

where $S_{0}$ is the initial solute $(\mathrm{mg} / \mathrm{g})$ in the raw noni fruits and $S_{\mathrm{t}}$ is the recovered solute $(\mathrm{mg} / \mathrm{g})$ after a certain time (min). The model parameters were determined using Matlab curve-fitting function.

\section{Results and Discussion}

\subsection{Effect of Subcritical Water Temperature}

In SWE, the extraction temperature plays an important role that affects the dielectric constant, viscosity, and surface tension of water, while pressure has little effect as long as the water remains liquid in the system $[24,31,32]$. In this study, the extraction yields of phenolic compounds were determined at $100-140^{\circ} \mathrm{C}$ and $2 \mathrm{~mL} / \mathrm{min}$ (Figure 2). The extraction (or recovery) yields (\%) of phenolic compounds were calculated based on the contents in the raw noni fruits (scopoletin: 533.4, rutin: 544.9, and alizarin: $23.4 \mu \mathrm{g} / \mathrm{g}$ dry matter). The scopoletin yield slightly increased at $120^{\circ} \mathrm{C}$, but significantly at $140{ }^{\circ} \mathrm{C}$ compared with $100^{\circ} \mathrm{C}$. The alizarin yields gradually increased as the temperature increased from 100 to $120^{\circ} \mathrm{C}$, but rapidly increased at $140^{\circ} \mathrm{C}$. The yield of rutin increased as the temperature increased from 100 to $120^{\circ} \mathrm{C}$, but at $140{ }^{\circ} \mathrm{C}$, it decreased due to thermal degradation. Kim and Lim [28] also experienced the degradation of rutin into low-molecular-weight compounds at over $120^{\circ} \mathrm{C}$ of water.
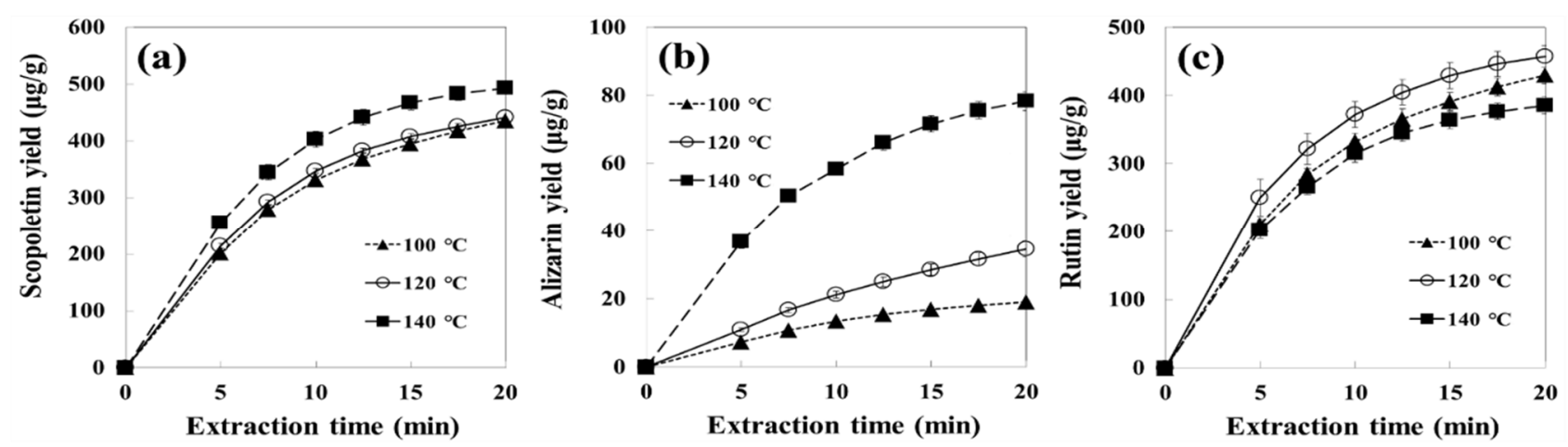

Figure 2. Effect of three different water temperatures on cumulative yields of (a) scopoletin, (b) alizarin, and (c) rutin under a water flow rate of $2 \mathrm{~mL} / \mathrm{min}$ from noni fruits extracted by subcritical water. Data are mean values $\pm \operatorname{SD}(n=3)$.

The scopoletin yields were $435.3,441.3$, and $493.3 \mu \mathrm{g} / \mathrm{g}$ dry sample $(81.6 \%, 82.7 \%$, and $92.4 \%$ compared with the content in the raw sample) at 100,120 , and $140{ }^{\circ} \mathrm{C}$, respectively (Table 1). Tatke and Rajan [33] reported that the yields of scopoletin were $7.9 \%, 9.5 \%$, $10.9 \%, 31.8 \%$, and $45.1 \%$ for supercritical fluid, Soxhlet, reflux, ultrasonic-assisted, and microwave-assisted extractions from Convolvulus pluricaulis, respectively. 
Table 1. The phenolic compound yields from noni fruits by subcritical water extraction at different temperatures and flow rates.

\begin{tabular}{cccccc}
\hline \multirow{2}{*}{ No. } & \multirow{2}{*}{$\begin{array}{c}\text { Temperature } \\
\left({ }^{\circ} \mathbf{C}\right)\end{array}$} & $\begin{array}{c}\text { Flow Rate } \\
(\mathbf{m L} / \mathbf{m i n})\end{array}$ & \multicolumn{2}{c}{ Extraction Yield ( $\mu$ g/g Dry Sample) } \\
\cline { 4 - 6 } & 100 & 1 & $364.2 \pm 11.7$ & $15.0 \pm 0.8$ & $372.9 \pm 11.7$ \\
1 & & 2 & $435.3 \pm 6.4$ & $19.1 \pm 0.3$ & $429.6 \pm 11.9$ \\
2 & & 3 & $444.8 \pm 3.3$ & $20.0 \pm 0.6$ & $437.3 \pm 4.8$ \\
3 & \multirow{2}{*}{120} & 1 & $382.1 \pm 9.5$ & $28.8 \pm 1.1$ & $375.5 \pm 12.0$ \\
4 & & 2 & $441.3 \pm 4.9$ & $34.5 \pm 2.3$ & $457.0 \pm 15.7$ \\
5 & & 3 & $492.6 \pm 11.9$ & $34.7 \pm 1.8$ & $476.2 \pm 16.6$ \\
6 & 140 & 1 & $416.4 \pm 3.2$ & $64.0 \pm 1.0$ & $368.8 \pm 2.6$ \\
7 & & 2 & $493.3 \pm 11.5$ & $78.3 \pm 2.8$ & $385.2 \pm 12.1$ \\
8 & & 3 & $530.6 \pm 22.1$ & $81.5 \pm 0.8$ & $452.0 \pm 16.2$ \\
9 & & & & & \\
\hline
\end{tabular}

Data are mean $\pm \operatorname{SD}(n=3)$.

The alizarin yields were $19.1,34.5$, and $78.3 \mu \mathrm{g} / \mathrm{g}$ dry sample $(81.6 \%, 147.4 \%$, and $334.6 \%$ compared with the content in the raw sample) at 100,120 , and $140{ }^{\circ} \mathrm{C}$, respectively. The alizarin contents of the extracts at 120 and $140{ }^{\circ} \mathrm{C}$ were higher than that contained in the original raw sample probably due to the hydrolysis of alizarin glycosides to their corresponding aglycones at high water temperature [34,35]. Alizarin is known to exist as free and glycoside forms, and the glycoside-to-aglycone ratio is known to be $237: 1 \mathrm{mg} / \mathrm{mL}$ in ethanol extract from the roots of Iranian madder [34,36,37]. The rutin yields were 429.6, 457.0 , and $385.2 \mu \mathrm{g} / \mathrm{g}$ dry sample $(78.8 \%, 83.8 \%$, and $70.6 \%$ compared with the content in the raw sample) at 100,120 , and $140{ }^{\circ} \mathrm{C}$, respectively.

The increase in extraction yield with water temperature is due to the decrease in dielectric constant, viscosity, and surface tension of water at high temperatures $[18,25]$. The dielectric constants of water at $20,100,120$, and $140{ }^{\circ} \mathrm{C}$ were $80.2,55.4,50.5$, and 46.0 , respectively [38]. The viscosities of water at 20,100,120, and $140^{\circ} \mathrm{C}$ were $1002 \times 10^{-6}, 281 \times 10^{-6}, 232 \times 10^{-6}$, and $196 \times 10^{-6} \mathrm{~Pa} \cdot \mathrm{s}$, respectively [39]. The surface tensions of water at $20,110,130$, and $150^{\circ} \mathrm{C}$ were $72.5,56.9,52.7$, and $48.3 \mathrm{mN} / \mathrm{m}$, respectively [38]. This unique property is an advantage to SW, where it can extract medium polar compounds using water as a green solvent.

\subsection{Effect of Water Flow Rate}

The effect of flow rate on the extraction yields of phenolic compounds from noni fruits was also investigated in the range of 1 to $3 \mathrm{~mL} / \mathrm{min}$ at $140{ }^{\circ} \mathrm{C}$ for scopoletin and alizarin, and at $120^{\circ} \mathrm{C}$ for rutin. The changes of the extraction rate with the water flow rate and water volume can give an idea on the extraction kinetics [22,24-26,40]. The yield significantly increased with the increase in flow rate from 1 to $2 \mathrm{~mL} / \mathrm{min}$, but slightly increased at $3 \mathrm{~mL} / \mathrm{min}$ (Figure 3a). The extraction curves were plotted against the water volume used, and all extraction curves were overlapped $(p<0.05)$ (Figure $3 b)$, which indicates that the yields of phenolic compounds were directly proportional to the volume of water passing through the sample. Therefore, the extraction process of phenolic compounds from noni fruits using SW seems to be controlled by external mass transfer.

The scopoletin yields were $416.4,493.3$, and $530.6 \mu \mathrm{g} / \mathrm{g}$ dry sample $(78.0 \%, 92.4 \%$, and $99.4 \%$ compared with the content in the raw sample) at $140{ }^{\circ} \mathrm{C}$ and 1,2 , and $3 \mathrm{~mL} / \mathrm{min}$, respectively. The yield of scopoletin by SWE at $140^{\circ} \mathrm{C}$ and $3 \mathrm{~mL} / \mathrm{min}$ for $20 \mathrm{~min}$ using $60 \mathrm{~mL}$ of water was $530.6 \mu \mathrm{g} / \mathrm{g}$ dry sample compared with $533.4 \mu \mathrm{g} / \mathrm{g}$ dry sample using $100 \mathrm{~mL}$ of neat methanol for $150 \mathrm{~min}$ at ambient temperature. Therefore, SWE has the advantage of using an eco-friendly solvent instead of organic solvents, a small amount of solvent, and a shortened extraction time. The alizarin yields were $64.0,78.3$, and $81.5 \mu \mathrm{g} / \mathrm{g}$ dry sample $(273 \%, 334 \%$, and $348 \%)$ at $140{ }^{\circ} \mathrm{C}$ and 1,2 , and $3 \mathrm{~mL} / \mathrm{min}$, respectively. The yields of rutin were $375.5,457.0$, and $476.2 \mu \mathrm{g} / \mathrm{g}$ dry sample $(68.9 \%, 83.8 \%$, and $87.3 \%)$ at $120^{\circ} \mathrm{C}$ and 1,2 , and $3 \mathrm{~mL} / \mathrm{min}$, respectively. During the extraction, increases in the concentration gradient 
of the solute between the sample matrix and water with an increasing flow rate lead to an increase in recovery yields [41].

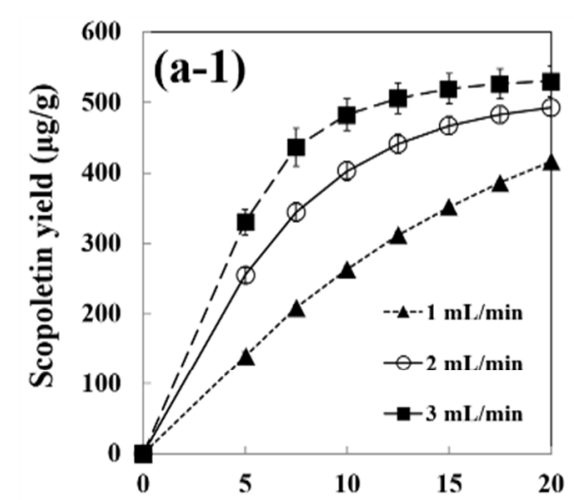

Extraction time (min)

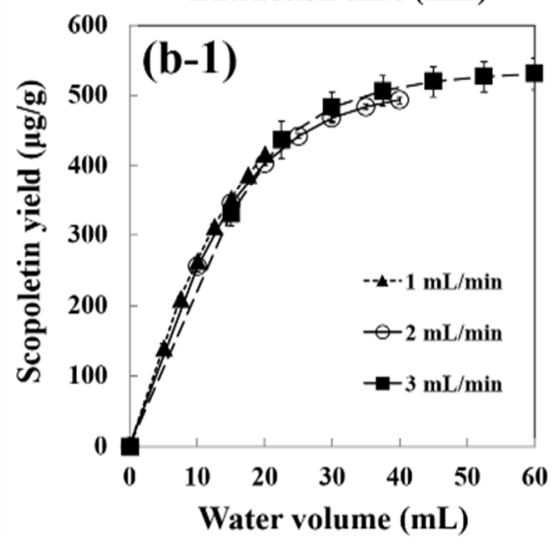

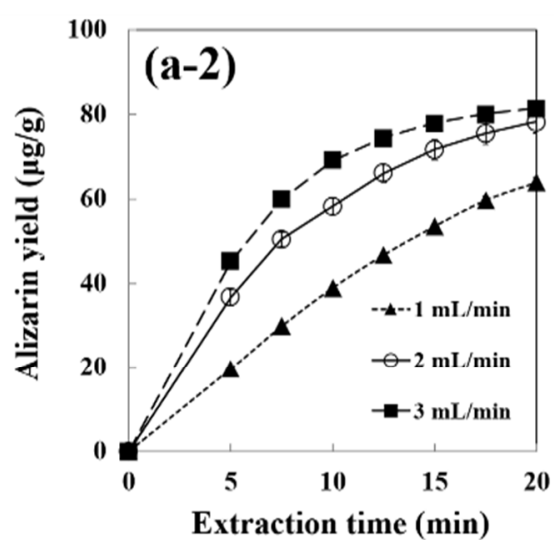
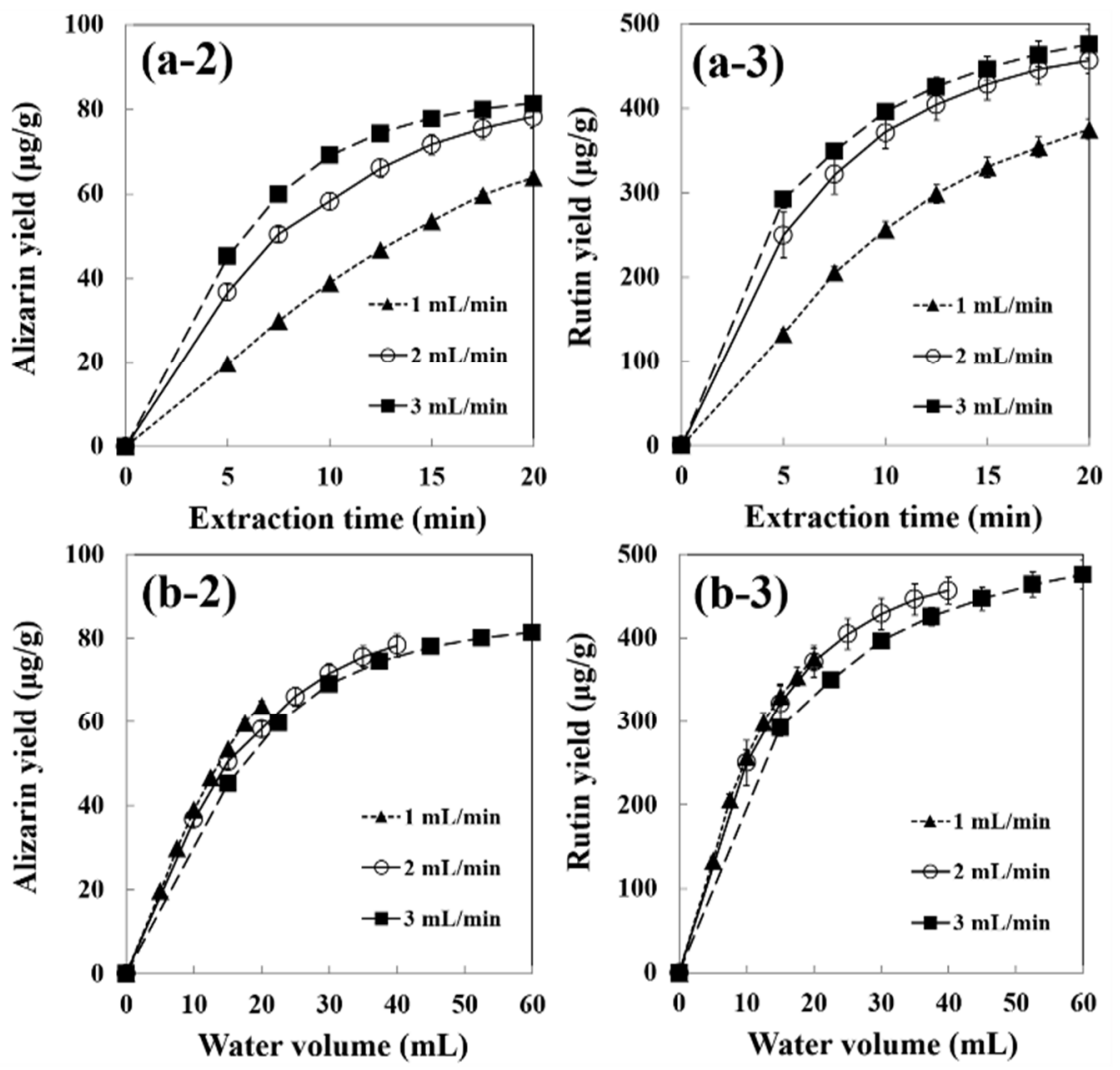

Figure 3. Effect of water flow rate (a) and water volume (b) on cumulative yields of scopoletin (a1,b1) at $140{ }^{\circ} \mathrm{C}$, alizarin $(\mathbf{a} 2, \mathbf{b} 2)$ at $140{ }^{\circ} \mathrm{C}$, and rutin $(\mathbf{a} 3, \mathbf{b} 3)$ at $120^{\circ} \mathrm{C}$ from noni fruits extracted by SWE. Data are mean $\pm \operatorname{SD}(n=3)$.

\subsection{Kinetic Modeling}

The extraction mechanism is important to understand how the extraction works on a certain compound from plant materials. Generally, the extraction process can be explained by intraparticle diffusion or elution of the solute from a solid matrix into a flowing solvent [22,23]. The initial concentrations of scopoletin and rutin in the raw sample were set to $C_{0}$ in the model equations. For alizarin, the maximum cumulative yield in the SW extract at $140{ }^{\circ} \mathrm{C}$ collected for $30 \mathrm{~min}$ was used as $\mathrm{C}_{0}$ in the model equations because the contents in the extracts were higher than those in the raw dried noni fruits due to the hydrolysis of alizarin glycosides to their corresponding aglycones at high water temperature.

The experimental data were fitted to the partition coefficient model, and the $K_{D}$ values of each compound were determined (Table 2). The $K_{D}$ values with different flow rates at the same temperature were the same $(p<0.05)$ and decreased as an increase in temperature from 100 to $140{ }^{\circ} \mathrm{C}$. The decrease in $K_{D}$ value with an increase in water temperature indicates an increase in recovery efficiency due to weakened competition of the solute between the sample matrix and water at high temperature [23,30]. Alizarin has high $K_{D}$ values (9.1-74.2) compared with scopoletin (7.2-9.3) and rutin (6.5-9.3) at $100-140{ }^{\circ} \mathrm{C}$. The $K_{D}$ value of alizarin was 8.2 -fold higher compared with that of scopoletin at $100^{\circ} \mathrm{C}$. However, the $K_{D}$ value of alizarin decreased rapidly as the temperature increased to $140{ }^{\circ} \mathrm{C}$ to become comparable to that of scopoletin probably due to the acceleration of hydrolysis of alizarin glycosides to alizarin aglycone in water at $140{ }^{\circ} \mathrm{C}[34,35]$. 
Table 2. Partitioning coefficients $\left(\mathrm{K}_{\mathrm{D}}\right)$ of bioactive compounds extracted by subcritical water fitted by the thermodynamic partitioning model.

\begin{tabular}{ccccc}
\hline \multirow{2}{*}{$\begin{array}{c}\text { Temperature } \\
\left({ }^{\circ} \mathbf{C}\right)\end{array}$} & $\begin{array}{c}\text { Flow Rate } \\
(\mathbf{m L} / \text { min) }\end{array}$ & Scopoletin & Alizarin & Rutin \\
\cline { 2 - 5 } 100 & 1 & $9.0 \pm 0.6^{\mathrm{a}}$ & $71.6 \pm 2.7^{\mathrm{a}}$ & $9.0 \pm 0.5^{\mathrm{a}}$ \\
& 2 & $9.1 \pm 0.5^{\mathrm{a}}$ & $70.2 \pm 1.9^{\mathrm{a}}$ & $9.2 \pm 0.4^{\mathrm{a}}$ \\
& 3 & $9.3 \pm 0.6^{\mathrm{a}}$ & $74.2 \pm 4.5^{\mathrm{a}}$ & $9.3 \pm 0.4^{\mathrm{a}}$ \\
120 & 1 & $8.1 \pm 0.4^{\mathrm{b}}$ & $51.2 \pm 2.5^{\mathrm{b}}$ & $6.7^{\mathrm{b}} \pm 0.2^{\mathrm{c}}$ \\
& 2 & $8.1 \pm 0.4^{\mathrm{b}}$ & $52.5 \pm 2.4^{\mathrm{b}}$ & $6.5^{\mathrm{b}} \pm 0.4^{\mathrm{c}}$ \\
& 3 & $7.5 \pm 0.5^{\mathrm{bc}}$ & $53.9 \pm 2.5^{\mathrm{b}}$ & $6.7 \pm 0.2^{\mathrm{c}}$ \\
140 & 1 & $7.2 \pm 0.1^{\mathrm{c}}$ & $9.6 \pm 0.3^{\mathrm{c}}$ & $7.8 \pm 0.1^{\mathrm{b}}$ \\
& 2 & $7.5 \pm 0.3^{\mathrm{bc}}$ & $9.2 \pm 0.8^{\mathrm{c}}$ & $7.9 \pm 0.6^{\mathrm{b}}$ \\
& 3 & $7.7 \pm 0.0^{\mathrm{bc}}$ & $9.1 \pm 0.5^{\mathrm{c}}$ & $7.5 \pm 0.3^{\mathrm{b}}$ \\
\hline
\end{tabular}

Data are mean \pm SD $(n=3)$. Mean values with different characters in each column are significantly different $(p<0.05$ by Duncan's multiple range test).

For the two-site kinetic model, two rate constants are calculated (Table S1). When the water temperature and flow rate were changed from $100{ }^{\circ} \mathrm{C}, 1 \mathrm{~mL} / \mathrm{min}$, to $140{ }^{\circ} \mathrm{C}$, $3 \mathrm{~mL} / \mathrm{min}$, the $k_{1}$ value for alizarin increased 18.3-fold compared with 3.88-fold for scopoletin and 3.56-fold for rutin. Likewise, the $f$ value for alizarin also increased 3.92-fold compared with 1.93-fold for scopoletin and 1.43-fold for rutin. The desorption rate constants of the slowly released fraction $\left(k_{2}\right)$ for all compounds increased with increasing extraction temperature but decreased with increasing water flow rate $(p<0.05)$ due to the increased internal mass transfer resistance with increasing water flow rate [42].

Figures 4 and 5 show the partition coefficient, and two-site kinetic model fits with the extraction data of phenolic compounds from noni fruits. The $K_{D}$ model had no good fit in their latter parts at a higher flow rate (Figure 4). On the contrary, all regression curves by the two-site kinetic desorption model had a better fit for three phenolic compounds at all extraction conditions (Figure 5).

To quantitatively prove the suitability of two kinetic models, the correlation coefficient $\left(R^{2}\right)$ and the root mean square error (RMSE) between the values predicted by each model equation were calculated (Table S2). For the $K_{D}$ model, almost all the extraction conditions show a relatively low RMSE $(\leq 0.047)$ and high $R^{2}(\geq 0.967)$. Conversely, the two-site kinetic model shows the lowest RMSE $(\leq 0.029)$ and highest $R^{2}(\geq 0.991)$ for all temperature and flow rates. This indicates the better suitability of the two-site kinetic model in describing the extraction kinetics of phenolic compounds from noni fruits. Since this model takes into account two different solute fractions (i.e., fast and slow extraction periods) and divides the extraction curve into two desorption rate constants, $k_{1}$ and $k_{2}$, it enables a better representation of all phases of the extraction curve [27]. The regression curves of the two-site kinetic desorption model for rutin were suitable for degradation temperature $\left(140{ }^{\circ} \mathrm{C}\right)$ and extraction temperatures $\left(100\right.$ and $\left.120^{\circ} \mathrm{C}\right)$. This is the first study to find that not only the extraction kinetic but also the degradation kinetic of rutin is well described by the two-site kinetic model in noni fruit using SW.

Most of the studies carried out in subcritical water extraction highlight fast and slow extraction behaviors $[26,27,29,43]$. Shotipruk et al. [24] examined pressurized hot water extraction of anthraquinones from dried roots of noni, and the extraction kinetic analysis suggested that the extraction process did not correspond strictly to any one of the cases, such as the intraparticle diffusion or thermodynamic partition. Anekpankul et al. [25] also investigated subcritical water extraction of damnacanthal from the dried root of noni, and the extraction was controlled by a combination of the intraparticle diffusion and thermodynamic partition, and the extraction behavior may vary depending on extraction conditions. 

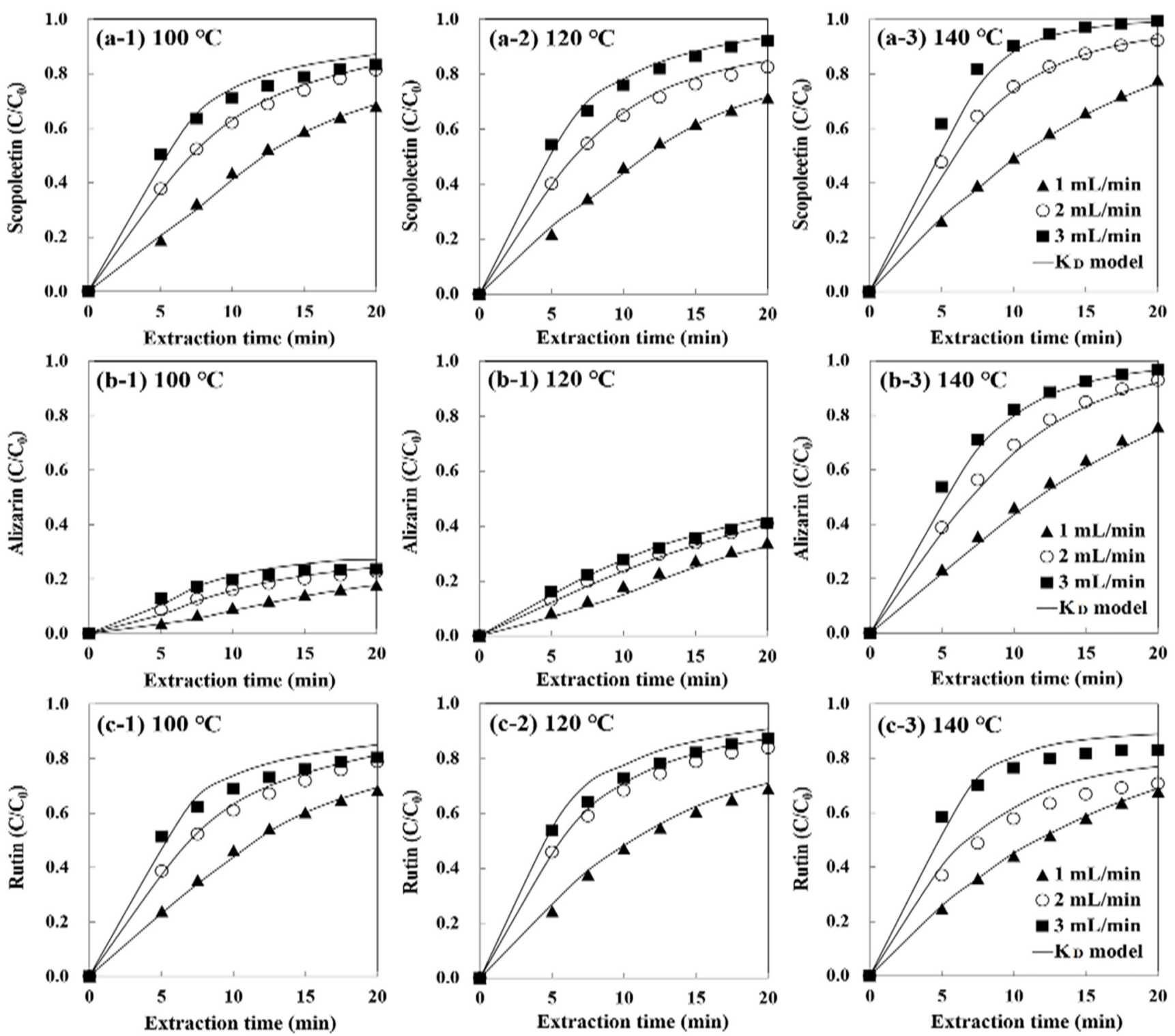

Figure 4. The thermodynamic partitioning model fit for the experimental data on subcritical water extraction of (a) scopoletin, (b) alizarin, and (c) rutin from noni fruits. The points represent the experimental values, and the solid lines are predicted in this model equation. 

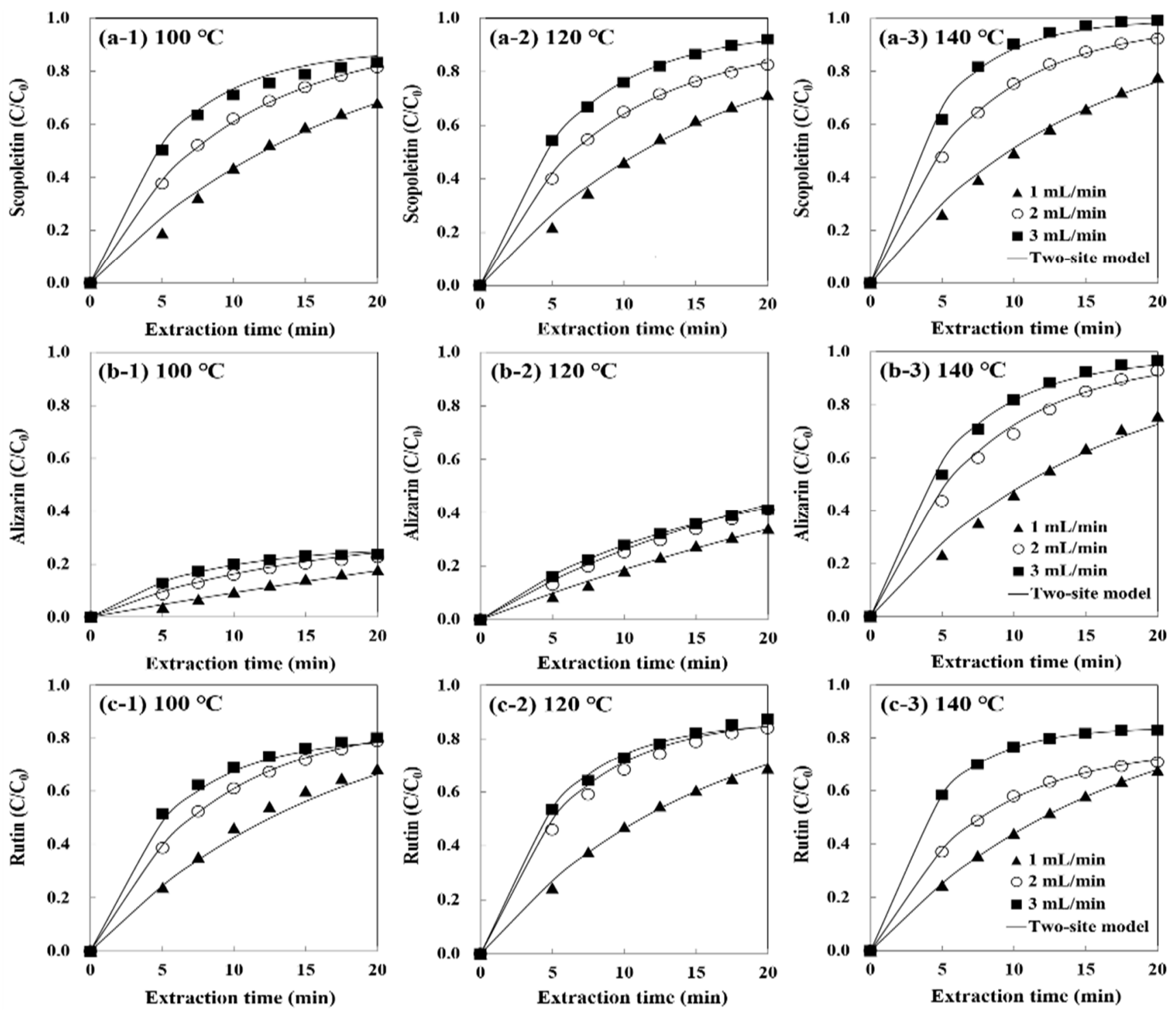

Figure 5. The two-site kinetic desorption model fit for the experimental values on subcritical water extraction of (a) scopoletin, (b) alizarin, and (c) rutin from noni fruits. The points represent the experimental values, and the solid lines are predicted in this model equation.

\subsection{Diffusion Coefficient and Activation Energy}

The mass transfer properties of phenolic compounds from noni fruits using SW were determined by the diffusion coefficient $\left(D_{e}\right)$ using the equation suggested by other authors $[23,44]$. The $D_{e}$ value of scopoletin was only $0.51 \times 10^{-9} \mathrm{~m}^{2} / \mathrm{s}$ at $100{ }^{\circ} \mathrm{C}, 1 \mathrm{~mL} / \mathrm{min}$, but increased to $1.93 \times 10^{-9} \mathrm{~m}^{2} / \mathrm{s}$ (3.7-fold) at $140^{\circ} \mathrm{C}, 3 \mathrm{~mL} / \mathrm{min}$ (Table 3$)$. The $D_{e}$ value of alizarin also increased 16.2-fold with increasing extraction temperature and flow rate from $100{ }^{\circ} \mathrm{C}, 1 \mathrm{~mL} / \mathrm{min}\left(0.09 \times 10^{-9} \mathrm{~m}^{2} / \mathrm{s}\right)$, to $140{ }^{\circ} \mathrm{C}, 3 \mathrm{~mL} / \mathrm{min}\left(1.46 \times 10^{-9} \mathrm{~m}^{2} / \mathrm{s}\right)$. The $D_{\mathrm{e}}$ values of rutin cannot be determined due to the thermal degradation at $140{ }^{\circ} \mathrm{C}$. 
Table 3. Diffusion coefficients of scopoletin and alizarin at various water temperatures and flow rates.

\begin{tabular}{cccc}
\hline \multirow{2}{*}{$\begin{array}{c}\text { Temperature } \\
\left({ }^{\circ} \mathbf{C}\right)\end{array}$} & $\begin{array}{c}\text { Flow Rate } \\
(\mathbf{m L} / \mathbf{m i n})\end{array}$ & \multicolumn{2}{c}{ Diffusion Coefficient $\left(\times \mathbf{1 0}^{-\mathbf{9}} \mathbf{~}^{\mathbf{2}} \mathbf{s}\right)$} \\
\cline { 3 - 4 } & 1 & $0.51 \pm 0.03^{\mathrm{f}}$ & Alizarin \\
\hline \multirow{2}{*}{100} & 2 & $0.71 \pm 0.03^{\text {de }}$ & $0.09 \pm 0.01^{\mathrm{f}}$ \\
& 3 & $0.96 \pm 0.02^{\mathrm{c}}$ & $0.19 \pm 0.00^{\text {ef }}$ \\
& 1 & $0.55 \pm 0.02^{\text {ef }}$ & $0.18 \pm 0.01^{\text {de }}$ \\
\hline \multirow{2}{*}{120} & 2 & $0.86 \pm 0.02^{\text {cd }}$ & $0.22 \pm 0.02^{\mathrm{d}}$ \\
& 3 & $1.20 \pm 0.03^{\mathrm{b}}$ & $0.25 \pm 0.03^{\mathrm{d}}$ \\
\hline \multirow{2}{*}{140} & 1 & $0.64 \pm 0.01^{\text {ef }}$ & $0.61 \pm 0.01^{\mathrm{c}}$ \\
& 2 & $1.14 \pm 0.13^{\mathrm{b}}$ & $1.02 \pm 0.07^{\mathrm{b}}$ \\
& 3 & $1.93 \pm 0.26^{\mathrm{a}}$ & $1.46 \pm 0.11^{\mathrm{a}}$ \\
\hline
\end{tabular}

Data are mean \pm SD $(n=3)$. Mean values with different characters in each column are significantly different $(p<0.05$ by Duncan's multiple range test).

The increases in $D_{e}$ value with increasing flow rate and temperature may be due to the increase in mobility of the solute at a high temperature [43] and the increase in the concentration gradient of the solute between the solvent and the sample [45,46]. Kim and Lim [44] also reported that the $D_{e}$ values of hesperidin and polymethoxyflavones from Citrus unshiu peel using SW increased from $0.13 \times 10^{-9}$ and $0.42 \times 10^{-9} \mathrm{~cm}^{2} / \mathrm{s}$ to $1.28 \times 10^{-9}$ and $1.62 \times 10^{-9} \mathrm{~cm}^{2} / \mathrm{s}$, respectively, as the increase in temperature and flow rate from $120^{\circ} \mathrm{C}$, $1 \mathrm{~mL} / \mathrm{min}$, to $160^{\circ} \mathrm{C}, 2 \mathrm{~mL} / \mathrm{min}$.

The activation energies $\left(E_{a}\right)$ for diffusion of scopoletin and alizarin at various flow rates were determined using the Arrhenius-type equation suggested by other authors [30,44]. The $E_{a}$ values of alizarin at all flow rates $(62.7-64.5 \mathrm{~kJ} / \mathrm{mol})$ were $2.9-$ to 8.5 -fold higher than those of scopoletin $(7.3-22.0 \mathrm{~kJ} / \mathrm{mol}$ ) at different flow rates (Table 4), probably because the solubility of neat alizarin is low in water [47]. Alizarin is almost insoluble in water, but readily soluble in alcohol and alkaline solutions [35]. The $E_{a}$ values of scopoletin increased from $7.3 \mathrm{~kJ} / \mathrm{mol}$ at $1 \mathrm{~mL} / \mathrm{min}$ to $22.0 \mathrm{~kJ} / \mathrm{mol}$ at $3 \mathrm{~mL} / \mathrm{min}$, while those of alizarin did not vary depending on the flow rate. This difference is probably due to the molecular structure or existing form in the sample matrix (scopoletin: free (aglycone), alizarin: bound (glycoside)). Kim and Lim [44] also reported that the $E_{a}$ value of polymethoxyflavones (aglycone) increased from 7.1 to $25.8 \mathrm{~kJ} / \mathrm{mol}$, while that of hesperidin (glycoside) decreased from 42.3 to $37.2 \mathrm{~kJ} / \mathrm{mol}$ with an increase in water flow rate from 1 to $2 \mathrm{~mL} / \mathrm{min}$.

Table 4. Activation energies of scopoletin and alizarin during subcritical water extraction.

\begin{tabular}{ccc}
\hline \multirow{2}{*}{$\begin{array}{c}\text { Flow Rate } \\
(\mathbf{m L} / \mathbf{m i n})\end{array}$} & \multicolumn{2}{c}{ Activation Energy (kJ/mol) } \\
\cline { 2 - 3 } & Scopoletin & Alizarin \\
\hline 1 & $7.3 \pm 1.3^{\mathrm{b}}$ & $62.7 \pm 2.0^{\mathrm{a}}$ \\
2 & $15.0 \pm 4.9^{\mathrm{ab}}$ & $63.6 \pm 1.8^{\mathrm{a}}$ \\
3 & $22.0 \pm 4.6^{\mathrm{a}}$ & $64.5 \pm 1.8^{\mathrm{a}}$
\end{tabular}

Data are mean \pm SD $(n=3)$. Mean values with different characters in each column are significantly different $(p<0.05$ by Duncan's test).

\section{Conclusions}

Bioactive phenolic compounds were extracted from noni fruits using a custom-made semicontinuous SWE system. The highest yields of scopoletin $(530.6 \mu \mathrm{g} / \mathrm{g}$ dry sample (99.4\% compared with the content in the raw sample)) and alizarin $(81.5 \mu \mathrm{g} / \mathrm{g}$ dry sample $(348 \%))$ were obtained at $140{ }^{\circ} \mathrm{C}, 3 \mathrm{~mL} / \mathrm{min}$, while that of rutin $(476.2 \mu \mathrm{g} / \mathrm{g}$ dry sample $(87.3 \%)$ ) was at $120^{\circ} \mathrm{C}, 3 \mathrm{~mL} / \mathrm{min}$. The two-site kinetic desorption model best describes the extraction kinetics of scopoletin, rutin, and alizarin from noni fruits under all extraction conditions using SW. The diffusion coefficients of scopoletin and alizarin increased about 3.78- and 16.2 -fold at $140{ }^{\circ} \mathrm{C}$ relative to $100^{\circ} \mathrm{C}$. The activation energy of scopoletin increased, 
while that of alizarin did not vary with an increase in the flow rate. The extraction kinetics revealed in this study could be useful to provide useful information for process design at the industrial level of subcritical water extraction devices. Further works are needed on the analysis of free (aglycone) and bound (glycoside) alizarins in the raw sample and the extracts.

Supplementary Materials: The following are available online at https:/ / www.mdpi.com/article/ 10.3390/foods10102260/s1: Figure S1: HPLC chromatograms of standard scopoletin and rutin at $350 \mathrm{~nm}$ and alizarin at $250 \mathrm{~nm}$, Figure S2: HPLC chromatograms of methanol extract from noni fruits: scopoletin (RT: 9.85) and rutin (RT: 11.36) at $350 \mathrm{~nm}$ (a), and alizarin (RT: 24.53) at $250 \mathrm{~nm}$ (b), Figure S3: HPLC chromatograms of subcritical water extract at $140{ }^{\circ} \mathrm{C}$ and $1 \mathrm{~mL} / \mathrm{min}$ from noni fruits: scopoletin (RT: 9.87) and rutin (RT: 11.39) at $350 \mathrm{~nm}$ (a), and alizarin (RT: 24.54) at $250 \mathrm{~nm}$ (b), Table S1: The values of $f, k_{1}$, and $k_{2}$ of bioactive compounds extracted by subcritical water fitted by the two-site kinetic model, Table S2: Determination coefficients and root mean square error values for the thermodynamic partitioning and two-site kinetic models.

Author Contributions: Conceptualization, methodology, data curation, formal analysis, investigation, writing —original draft, R.J. and D.-S.K.; conceptualization, project administration, writingreview and editing, supervision, L.M.S. and S.-B.L.; funding acquisition, S.-B.L. All authors have read and agreed to the published version of the manuscript.

Funding: This research received no external funding.

Institutional Review Board Statement: Not applicable.

Informed Consent Statement: Not applicable.

Data Availability Statement: Data are not shared.

Acknowledgments: This research was partially supported by the 2020 scientific promotion program funded by Jeju National University. The authors would also like to express their gratitude to the School of Chemical and Energy Engineering, Faculty of Engineering, Universiti Teknologi Malaysia.

Conflicts of Interest: The authors declare no conflict of interest.

\section{References}

1. Ali, M.; Kenganora, M.; Manjula, S.N. Health benefits of Morinda citrifolia (Noni): A review. Pharmacogn. J. 2016, 8, 321-334. [CrossRef]

2. Torres, M.A.O.; de Fátima Braga Magalhães, I.; Mondêgo-Oliveira, R.; de Sá, J.C.; Rocha, A.L.; Abreu-Silva, A.L. One plant, many uses: A review of the pharmacological applications of Morinda citrifolia. Phyther. Res. 2017, 31, 971-979. [CrossRef] [PubMed]

3. Lee, D.; Yu, J.S.; Huang, P.; Qader, M.; Manavalan, A.; Wu, X.; Kim, J.C.; Pang, C.; Cao, S.; Kang, K.S.; et al. Identification of anti-inflammatory compounds from Hawaiian noni (Morinda citrifolia L.) fruit Juice. Molecules 2020, 25, 4968. [CrossRef] [PubMed]

4. Chan-Blanco, Y.; Vaillant, F.; Mercedes Perez, A.; Reynes, M.; Brillouet, J.M.; Brat, P. The noni fruit (Morinda citrifolia L.): A review of agricultural research, nutritional and therapeutic properties. J. Food Comp. Anal. 2006, 19, 645-654. [CrossRef]

5. Mahanthesh, M.C.; Manjappa, A.S.; Shindhe, M.V.; Jamkhandi, C.M.; Jalapure, S.S.; Patil, S.S. Morinda citrifolia Linn; a medicinal plant with diverse phytochemicals and its medicinal relevance. World J. Pharm. Res. 2013, 3, 215-232.

6. Assi, R.A.; Darwis, T.; Abdulbaqi, I.M.; Khan, A.A.; Vuanghao, L.; Laghari, M.H. Morinda citrifolia (Noni): A comprehensive review on its industrial uses, pharmacological activities, and clinical trials. Arab. J. Chem. 2017, 10, 691-707. [CrossRef]

7. Inada, A.C.; Figueiredo, P.S.; Santos-Eichler, R.A.; Freitas, K.C.; Hiane, P.A.; de Castro, A.P.; de Cássia Avellaneda Guimarães, R. Morinda citrifolia Linn. (noni) and its potential in obesity-related metabolic dysfunction. Nutrients 2017, 9, 540. [CrossRef]

8. Choi, R.Y.; Ham, J.R.; Lee, H.I.; Cho, H.W.; Choi, M.S.; Park, S.K.; Lee, J.; Kim, M.J.; Seo, K.I.; Lee, M.K. Scopoletin supplementation ameliorates steatosis and inflammation in diabetic mice. Phyther. Res. 2017, 31, 1795-1804. [CrossRef]

9. Ding, Z.; Dai, Y.; Hao, H.; Pan, R.; Yao, X.; Wang, Z. Anti-inflammatory effects of scopoletin and underlying mechanisms. Pharm. Biol. 2008, 46, 854-860. [CrossRef]

10. Hornick, C.A.; Myers, A.; Sadowska, K.H.; Anthony, C.T.; Woltering, E.A. Inhibition of angiogenic initiation and disruption of newly established human vascular networks by juice from Morinda citrifolia (noni). Angiogenesis 2003, 6, 143-149. [CrossRef]

11. Fotia, C.; Avnet, S.; Granchi, D.; Baldini, N. The natural compound alizarin as an osteotropic drug for the treatment of bone tumors. J. Orthop. Res. 2012, 30, 1486-1492. [CrossRef] [PubMed]

12. Pandy, V.; Narasingam, M.; Kunasegaran, T.; Murugan, D.D.; Mohamed, Z. Effect of noni (Morinda citrifolia Linn.) fruit and its bioactive principles scopoletin and rutin on rat vas deferens contractility: An ex vivo study. Sci. World J. 2014, 8, 909586. 
13. Huang, R.; Shi, Z.; Chen, L.; Zhang, Y.; Li, J.; An, Y. Rutin alleviates diabetic cardiomyopathy and improves cardiac function in diabetic ApoEknockout mice. Eur. J. Pharmacol. 2017, 814, 151-160. [CrossRef]

14. Hawthorne, S.B.; Grabanski, C.B.; Martin, E.; Miller, D.J. Comparisons of Soxhlet extraction, pressurized liquid extraction, supercritical fluid extraction and subcritical water extraction for environmental solids: Recovery, selectivity and effects on sample matrix. J. Chromatogr. A 2000, 892, 421-433. [CrossRef]

15. Barba, F.J.; Zhenzhou, Z.; Koubaa, M.; Sant'Ana, A.S.; Orlien, V. Green alternative methods for the extraction of antioxidant bioactive compounds from winery wastes and by-products: A review. Trends Food Sci. Technol. 2016, 49, 96-109. [CrossRef]

16. Ameer, K.; Shahbaz, H.M.; Kwon, J.H. Green extraction methods for polyphenols from plant matrices and their byproducts: A review. Compr. Rev. Food Sci. Food Saf. 2017, 16, 295-315. [CrossRef]

17. Mortazavi, S.V.; Eikani, M.H.; Mirzaei, H.; Jafari, M.; Golmohammad, F. Extraction of essential oils from Bunium persicum Boiss. using superheated water. Food Bioprod. Process. 2010, 88, 222-226. [CrossRef]

18. Plaza, M.; Turner, C. Pressurized hot water extraction of bioactives. Trends Anal. Chem. 2015, 71, 39-54. [CrossRef]

19. Castro-Puyana, M.; Marina, M.L.; Plaza, M. Water as green extraction solvent: Principles and reasons for its use. Curr. Opin. Green Sustain. Chem. 2017, 5, 31-36. [CrossRef]

20. Sarfarazi, M.; Jafari, S.M.; Rajabzadeh, G.; Feizi, J. Development of an environmentally-friendly solvent-free extraction of saffron bioactives using subcritical water. LWT-Food Sci. Technol. 2019, 114, 108428. [CrossRef]

21. Cheng, Y.; Xue, F.; Yu, S.; Du, S.; Yang, Y. Subcritical water extraction of natural products. Molecules 2021, 26, 4004. [CrossRef]

22. Kim, J.W.; Mazza, G. Mass transfer during pressurized low-polarity water extraction of phenolics and carbohydrates from flax shives. Ind. Eng. Chem. Res. 2007, 46, 7221-7230. [CrossRef]

23. Asl, A.H.; Khajenoori, M. Subcritical water extraction. In Mass Transfer-Advances in Sustainable Energy and Environment Oriented Numerical Modeling; Nakajima, H., Ed.; InTech: Rijeka, Croatia, 2013; pp. 464-465.

24. Shotipruk, A.; Kiatsongserm, J.; Pavasant, P.; Goto, M.; Sasaki, M. Pressurized hot water extraction of anthraquinones from the roots of Morinda citrifolia. Biotechnol. Prog. 2004, 20, 1872-1875. [CrossRef] [PubMed]

25. Anekpankul, T.; Goto, M.; Sasaki, M.; Pavasant, P.; Shotipruk, A. Extraction of anti-cancer damnacanthal from roots of Morinda citrifolia by subcritical water. Sep. Purif. Technol. 2007, 55, 343-349. [CrossRef]

26. Barrera Vázquez, M.F.; Comini, L.R.; Milanesio, J.M.; Núnez Montoya, S.C.; Cabrera, J.L.; Bottini, S.; Martini, R.E. Pressurized hot water extraction of anthraquinones from Heterophyllaea pustulata Hook f. (Rubiaceae). J. Supercrit. Fluids 2015, 101, 170-175. [CrossRef]

27. Duba, K.S.; Casazza, A.A.; Mohamed, H.B.; Perego, P.; Fiori, L. Extraction of polyphenols from grape skins and defatted grape seeds using subcritical water: Experiments and modeling. Food Bioprod. Process. 2015, 94, 29-38. [CrossRef]

28. Kim, D.S.; Lim, S.B. Subcritical water extraction of rutin from the aerial parts of common buckwheat. J. Supercrit. Fluids 2019, 152, 104561. [CrossRef]

29. Mufari, J.R.; Rodríguez-Ruiz, A.C.; Bergesse, A.E.; Miranda-Villa, P.P.; Nepote, V.; Velez, A.R. Bioactive compounds extraction from malted quinoa using water-ethanol mixtures under subcritical conditions. LWT-Food Sci. Technol. 2021, $138,110574$. [CrossRef]

30. Islam, M.N.; Jo, Y.T.; Jung, S.K.; Park, J.H. Thermodynamic and kinetic study for subcritical water extraction of PAHs. J. Ind. Eng. Chem. 2013, 19, 29-136. [CrossRef]

31. Ahmadian-Kouchaksaraie, Z.; Niazmand, R.; Najafi, M.N. Optimization of the subcritical water extraction of phenolic antioxidants from Crocus sativus petals of saffron industry residues: Box-Behnken design and principal component analysis. Innov. Food Sci. Emerg. Technol. 2016, 36, 234-244. [CrossRef]

32. Munir, M.T.; Kheirkhah, H.; Baroutian, S.; Quek, S.Y.; Young, B.R. Subcritical water extraction of bioactive compounds from waste onion skin. J. Clean. Prod. 2018, 183, 487-494. [CrossRef]

33. Tatke, P.; Rajan, M. Comparison of conventional and novel extraction techniques for the extraction of scopoletin from Convolvulus Pluricaulis. Ind. J. Pharm. Educ. Res. 2014, 48, 27-31. [CrossRef]

34. Derksen, G.C.H.; Naayer, M.; van Beek, T.A.; Capelle, A.; Haaksman, I.K.; van Doren, H.A.; de Groot, A. Chemical and enzymatic hydrolysis of anthraquinone glycosides from Madder roots. Phytochem. Anal. 2003, 14, 137-144. [CrossRef]

35. De Santis, D.; Moresi, M. Production of alizarin extracts from Rubia tinctorum and assessment of their dyeing properties. Ind. Crop. Prod. 2007, 26, 151-162. [CrossRef]

36. Caro, Y.; Anamale, L.; Fouillaud, M.; Laurent, P.; Petit, T.; Dufosse, L. Natural hydroxyl anthraquinoid pigments as potent food grade colorants: An overview. Nat. Prod. Bioprospect. 2012, 2, 174-193. [CrossRef]

37. Ford, L.; Rayner, C.M.; Blackburn, R.S. Isolation and extraction of ruberythric acid from Rubia tinctorum L. and crystal structure elucidation. Phytochemistry 2015, 117, 168-173. [CrossRef]

38. Brunner, G. Hydrothermal and Supercritical Water Process; Kiran, D., Ed.; Elsevier: Amsterdam, The Netherlands, $2014 ;$ p. 77.

39. Sengers, J.V.; Watson, J.T.R. Improved international formulations for the viscosity and thermal conductivity of water substance. J. Phys. Chem. Ref. Data 1986, 15, 1291-1314. [CrossRef]

40. Pongnaravane, B.; Goto, M.; Sasaki, M.; Anekpankul, T.; Pavasant, P.; Shotipruk, A. Extraction of anthraquinones from roots of Morinda citrifolia by pressurized hot water: Antioxidant activity of extracts. J. Supercrit. Fluids 2006, 37, 390-396. [CrossRef]

41. Shabkhiz, M.A.; Eikani, M.H.; Sadr, Z.B.; Golmohammad, F. Superheated water extraction of glycyrrhizic acid from licorice root. Food Chem. 2016, 210, 396-401. [CrossRef] [PubMed] 
42. Sovová, H. Steps of supercritical fluid extraction of natural products and their characteristic times. J. Supercrit. Fluids 2012, 66, 73-79. [CrossRef]

43. Ho, C.H.L.; Cacace, J.E.; Mazza, G. Mass transfer during pressurized low polarity water extraction of lignans from flaxseed meal. J. Food Eng. 2008, 89, 64-71. [CrossRef]

44. Kim, D.S.; Lim, S.B. Kinetic study of subcritical water extraction of flavonoids from citrus unshiu peel. Sep. Purif. Technol. 2020, 250, 117259. [CrossRef]

45. Al-Hamimi, S.; Mayoral, A.A.; Cunico, L.P.; Turner, C. Carbon dioxide expanded ethanol extraction: Solubility and extraction kinetics of $\alpha$-pinene and cis-verbenol. Anal. Chem. 2016, 88, 4336-4345. [CrossRef] [PubMed]

46. Mottahedin, P.; Asl, A.H.; Khajenoori, M. Extraction of curcumin and essential oil from Curcuma longa L. by subcritical water via response surface methodology. J. Food Process. Preserv. 2017, 41, e13095. [CrossRef]

47. Lakhotiya, H.; Mondal, K.; Nagarale, R.K.; Sharma, A. Low voltage non-gassing electro-osmotic pump with zeta potential tuned aluminosilicate frits and organic dye electrodes. RSC Adv. 2014, 4, 28814-28821. [CrossRef] 